Portland State University

PDXScholar

$9-24-2021$

\title{
The Worth of Risk: Political Participation and Risk Perceptions
}

Siri Grubb

Portland State University

Follow this and additional works at: https://pdxscholar.library.pdx.edu/open_access_etds

Part of the Communication Commons, and the Political Science Commons Let us know how access to this document benefits you.

\section{Recommended Citation}

Grubb, Siri, "The Worth of Risk: Political Participation and Risk Perceptions" (2021). Dissertations and Theses. Paper 5797.

https://doi.org/10.15760/etd.7668

This Thesis is brought to you for free and open access. It has been accepted for inclusion in Dissertations and Theses by an authorized administrator of PDXScholar. Please contact us if we can make this document more accessible: pdxscholar@pdx.edu. 
The Worth of Risk: Political Participation and Risk Perceptions

by

Siri Grubb

A thesis submitted in partial fulfillment of the requirements for the degree of

\author{
Master of Science \\ in \\ Communication
}

Thesis Committee:

Brianne Suldovsky, Chair

Lauren Frank

Lee Shaker

Portland State University

2021 


\begin{abstract}
This study draws on concepts from political and risk communication to inform our understanding of what motivates people to be politically active. Inspired by concerns that traditional models of participation do not perform as well among younger and more diverse populations (e.g. Bennett, 2008), alternate variables are considered including risk perceptions surrounding policy issues and political parties. Results show that established political variables such as political interest and civic duty remain strongly associated with participation, while offering support for several new variables of interest from the risk communication literature. In the present study, threat and efficacy perceptions explained additional variance in political participation when added to known predictors of participation.
\end{abstract}


Table of Contents

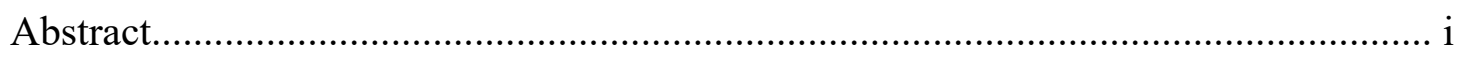

List of Tables ............................................................................................... iii

Introduction and Literature Review .................................................................. 1

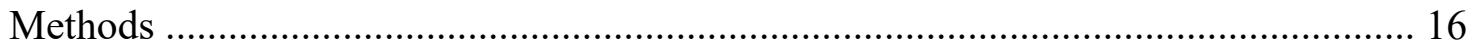

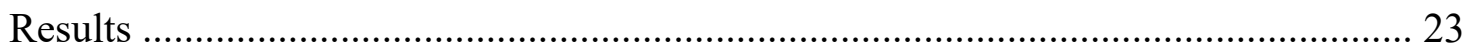

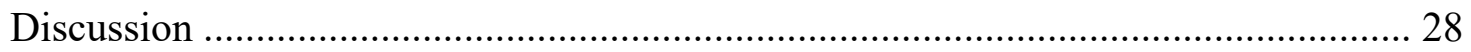

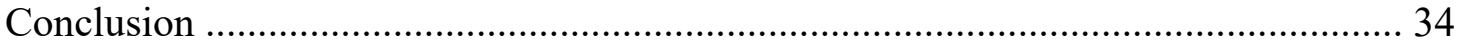

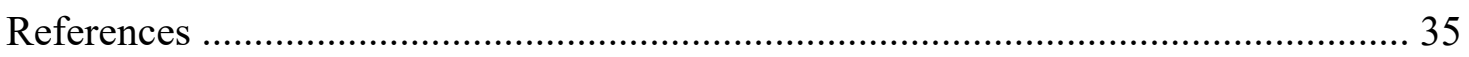

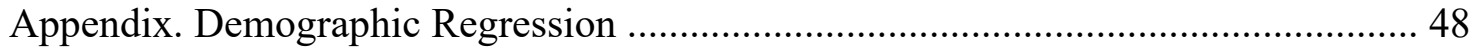




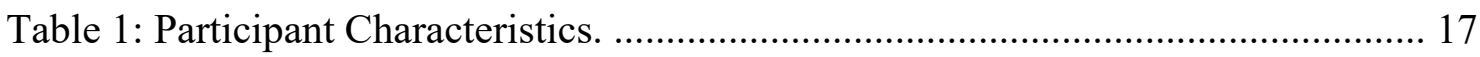

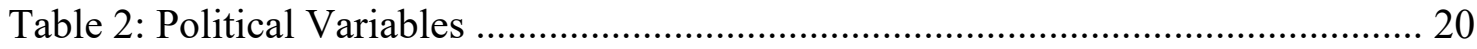

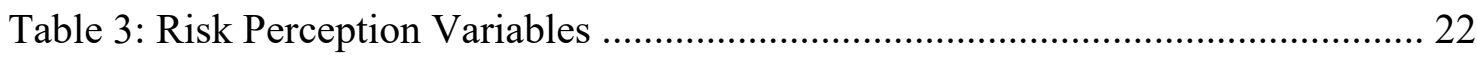

Table 4: Affective Polarization Variables .................................................................. 23

Table 5: Results of Multiple Regression Analyses ................................................ 25

Table 6: Results of Hierarchical Multiple Regression Analyses, RQ1 and RQ2 .......... 26

Table 7: Results of Hierarchical Multiple Regression Analyses, RQ3 ......................... 27 


\section{Introduction and Literature Review}

Risks are an inevitable part of life. While some risks exist at the level of the individual, many of the risks we experience exist at a societal level. From traffic accidents to earthquakes to climate change, addressing these shared risks is achieved, in part, through political action (Koski, 2010; May, 1991; Moser \& Dilling, 2011). Two branches of the field of communication focus on understanding perceptions of these shared risks: risk communication and political communication. Broadly speaking, risk communication scholars study how people perceive risks, and how best to design and disseminate messages that promote risk awareness and inspire people to take action (Lundgreen \& McKaien, 2013; Moser \& Dilling, 2011; Ruhrmann, 2008). Political communication scholars study how public perception of issues translates into public opinion, support for public policy, and political engagement (Bennett \& Iyengar, 2008; Ryfe, 2001). While risk and political communication typically focus on distinct communication phenomena, integrations of concepts from these two fields - though rare - indicate a potential for advances in our understanding of political participation (e.g. Glasford, 2008; Hart \& Feldman, 2016; O’Connor, Bard, \& Fisher, 1999).

One of the ways in which publics can address risk, both at the individual and societal levels, is through political participation (O'Connor, Bard, \& Fisher, 1999). This includes voting and other means of influencing the selection and decision-making of government officials. As an example, scientists, scholars, and advocates agree that any plan to address climate change must have a policy component (e.g. Hart \& Feldman, 2016; Moser \& Dilling, 2011; O’Connor, Bard, \& Fisher, 1999). Through political 
participation, citizens can influence which shared risks are addressed by government and how. Trends in electoral participation can offer some insight into who engages in political participation and, thus, shapes the way shared risks are addressed. After decades of steady decline, electoral participation in the United States increased considerably in the 2018 midterm and 2020 presidential elections (Campbell, 2006; Norris, 2015; Persily \& Stewart III, 2021). Whereas there has been long-standing concern about the engagement of younger citizens in politics, turnout in 2018 and 2020 increased most sharply among young voters (Cilluffo \& Fry, 2019; Fabina, 2021). This abrupt reversal raises the need to review known predictors of participation and consider new variables that can shed light on who participates in politics and why.

Current models in political communication have identified some reliable antecedents of voter participation, including demographics (Leighley \& Nagler, 2013; Wolfinger \& Rosenstone, 1980), political interest (Blais, 2000; Prior, 2010), political efficacy (Abramson \& Aldrich, 1982; Campbell, 2006; Craig, 1979; Shore, 2020), and civic duty (Blais \& Daost, 2020; Cambell, 2006; Delli Carpini, 2000; Riker \& Oldeshook, 1968). Similarly, current models in risk communication identify antecedents to individual and collective risk mitigation behaviors, including risk perceptions (Witte, 1992), and self-efficacy (Bandura, 1986; Witte, 1992).

While typically siloed, I offer that combining insights derived from both risk and political communication may lead to a more holistic understanding of the variables associated with risk-related political behavior. I measured variables from both fields that are known predictors of behavioral intention and investigated the relative importance of each in predicting political participation. In what follows, I describe the variables known 
to affect political participation and adoption of preventative risk behaviors. I then discuss how policy issues and political parties have been framed as risks to the general public. I propose that individuals' risk and efficacy perceptions offer additional insight into who participates and why.

\section{Political Communication}

\section{Who Participates in Politics}

Understanding who doesn't participate in politics begins with looking at who does. In the present study, political participation refers to actions taken to influence the selection or decisions of government actors. A prominent example of political participation is voting. While the electorate has been steadily growing younger and more diverse (Barroso, 2020), those who participate in politics remain disproportionately white, wealthy, educated, and (relatively) old (Leighley \& Nagler, 2013; Wolfinger \& Rosenstone, 1980). Though these demographic factors - particularly age, income, and education - are among the strongest predictors of electoral participation (Brady, Verba, \& Schlozman, 1995; Leighley \& Nagler, 2013; Wolfinger \& Rosenstone, 1980), there are several other individual-level variables that are consistently included in turnout models, including political interest, political efficacy, and civic duty. While some evidence suggests that the resources and advantages that precede electoral participation also influence who engages in other forms of participation (Best \& Krueger, 2005), there is some indication that alternate forms of political participation — particularly onlineattract younger and more diverse citizens (Bennett, 2008; Bennett, Wells, \& Rank, 2009; Best \& Krueger, 2005; Omotayo \& Folorunso, 2020). 
Political Interest. As a variable related to political behavior, interest is fairly intuitive: people who are interested in politics participate in politics. Though the causal pathway is somewhat unclear, political interest is commonly used to explain variance in participation (Blais \& Daoust, 2020; Brady, Verba, \& Schlozman, 1995; Prior, 2010). Literature suggests that political interest is a fairly stable, trait-like variable that develops early in life. Though it can fluctuate in response to personal and situational factors, it quickly rebounds to its long-term level (Prior, 2010).

Civic Duty. Blais (2000) describes civic duty as "an ethical judgement that voting is right and not voting is wrong" (p. 93). He distinguishes civic duty from political interest, claiming that the former is moral and represents a sense of what one ought to do (Blais \& Daoust, 2020). Citizens with a strong sense of civic duty often gain satisfaction from electoral participation, regardless of the outcome. For this reason, Riker and Oldeshook (1968) added it to their calculus of voting - a participation model that builds on Downs' (1957) rational choice model. Here, it offers an explanation for a problem that continues to plague rational choice scholars: why do people participate in elections when they know their vote is statistically inconsequential? Because civic duty is considered to be an important antecedent to political and civic participation, fostering civic duty through socialization and education is often recommended by scholars. Nevertheless, there is a decreasing trend in civic duty, especially in recent generations.

Political Efficacy. Political efficacy refers to the subjective attitudes that inform political behavior. The definition commonly used by scholars is "the feeling that individual political action does have, or can have, an impact upon the political process... It is the feeling that political and social change is possible, and that the individual citizen 
can play a part in bringing about this change" (Campbell, Gurin, \& Miller, 1954, p. 187). Political efficacy comprises two dimensions: internal and external.

Internal Efficacy. Internal efficacy captures an individual's evaluation of their ability to participate in politics. This includes both a perception that the opportunity for participation is accessible and a feeling of personal competence (Niemi, Craig, \& Mattei, 1991). Internal efficacy is assumed to be a direct precursor to participation (Shore, 2020), but also acts as a mediator. Research shows that internal efficacy mediates the relationship between socio-economic factors and participation, as people who are more educated and well-connected feel more confident in their ability to participate in politics (Shore, 2020). This cuts the other way, as Marx and Nguyen (2016) find that the depressive effects of poverty on participation are mediated by low internal efficacy. Internal efficacy also helps explain the relationship between political knowledge and participation. The mediating role of internal efficacy might be articulated as the subjective evaluation of one's political knowledge, or the feeling that one knows enough to participate meaningfully in politics (Reichert, 2016).

External Efficacy. External efficacy measures perceptions of the responsiveness of government to citizen influence attempts (Craig, 1979). That is, the extent to which people believe that participation is a viable way to influence government officials. As with internal efficacy, external efficacy has a direct relationship to participation (Rumbul, 2016) and also mediates the relationship between participation and individual-level factors like wealth (Marx \& Nguyen, 2018), education (Jackson, 1995), and social capital. Abramson and Aldrich (1982) estimate that at least half of the decline in voter 
turnout between 1960 and 1980 can be attributed to a decline in external political efficacy.

Consistent with this prior research, I offer the following hypothesis:

H1: Political interest, civic duty, internal efficacy, and external efficacy predicts political participation.

\section{Why People Participate in Politics}

In addition to understanding who participates, it is worthwhile to consider why people participate. Campbell (2006) describes a continuum anchored by two perspectives on civic and political involvement, dating back to the earliest conceptualizations of democracy in the United States: one is that citizens are motivated to participate out of a sense of duty, and the other is that they participate in order to advance their own interests. Campbell (2006, p. 193) notes that interest-driven citizens "ask themselves: Do I need to vote in this election to defend my interests?" A similar typology is offered by Bennett (2008; Bennett, Wells, \& Rank, 2009) who describes a shift in recent decades away from a dutiful citizen paradigm, in which one votes out of a sense of civic duty, toward an actualizing citizen paradigm characterized by involvement driven by interest in “personally meaningful, lifestyle-related political issues" (Bennett, 2008, p. 20). Though this is perhaps most visible among recent generations, not all actualizing citizens are young. According to Bennett, the shift is, in part, a product of cultural changes that have replaced group-based society with a network-based society - a change that has the potential to affect people across generations.

A potential shortcoming, then, of communication efforts aimed at increasing participation is an assumption that civic duty is still a primary motivator. This is not to 
say that fostering civic duty is not a worthwhile endeavor. Certainly, research shows that a sense of civic duty is a powerful motivator for participation — not only in elections but in other vital expressions of community and political involvement (Campbell, 2006). However, there is a growing need to consider models that better account for actualizing citizens. Bennett notes that actualizing citizens are characterized by a lack of trust in traditional forms of participation (i.e. voting), an observation echoed in Delli Carpini's (2000) examination of civic disengagement. While these citizens may prefer alternate forms of participation or forgo participation altogether, voting remains critical to the legitimacy and health of our democracy (Campbell, 2006). In order to increase the participation of actualizing citizens, we need to better understand their interests and motivations.

Despite decades of research and numerous models that focus on or combine individual, political, and contextual variables, there are persistent unexplained gaps in what we know about political participation (Matsusaka \& Palda, 1999). Studies repeatedly highlight the need for future research to uncover more factors that affect involvement, particularly among younger citizens (e.g. Glasford, 2008; Matsusaka \& Palda, 1999).

\section{Risk Communication}

Risk communication theory could provide additional insights by offering a new way to think about political participation. For citizens who are keen to advance or protect their interests, participation might be a means to that end. If failing to protect their interests is recontextualized as a risk, then participation could be characterized as a preventative risk behavior. The risk communication field is replete with strategies for 
understanding and promoting such behaviors (e.g. Azjen, 1991; Bandura, 1986; Bandura 2004; Witte, 1992). One concern central to risk communication is how individuals process and react to fear appeal-based messaging (Leventhal, 1970; Rogers, 1975; Witte, 1992), as fear appeals are a common tactic used by risk communicators (Popova, 2012). Appeals to fear are also a common tactic used in political communication, as partisan actors attempt to associate the opposition with feared outcomes, or to change attitudes by prompting viewers to critically process new information (Brader, 2006; Cryderman \& Arceneaux, 2010; Scheller, 2019). Given the potential to re-frame political involvement as a risk mitigation behavior and the prevalence of fear appeals in both risk and political communication, risk communication may offer additional insights that more holistically explain participatory behavior.

\section{The Extended Parallel Process Model}

One fear appeal theory with components that align with political participation variables is the extended parallel process model (EPPM; Witte, 1992). The EPPM grew out of previous work attempting to explain the inconsistent success of fear appeals in health communication. The earlier parallel process model (Leventhal, 1970) identified two general responses to fear appeals: danger control - a primarily cognitive processand fear control—a primarily emotional process. As emphasis in the field shifted to cognitive behavioral approaches, subsequent work on fear appeals focused on danger control - particularly the elements and approaches that motivated cognitive appraisal of fear inducing behavioral-change messages. Out of this work emerged the Protection Motivation Theory (PMT; Rogers, 1975), which identified message characteristics that led to adaptive or maladaptive responses to fear appeals. Incorporating Bandura's (1986) 
notion of self-efficacy, Rogers proposed that only messages which successfully instilled a confidence in the individual's ability to perform the recommended action would lead to message acceptance and adoption of the adaptive behavior. Despite decades of subsequent research, however, these theories and models failed to produce consistent empirical results. They could not reliably represent the role and interaction of the variables, and overwhelmingly focused on danger control to the exclusion of fear control. To address these deficiencies and inconsistencies, Witte (1992) developed the extended parallel process model, claiming that threat perceptions and efficacy perceptions interact to produce message acceptance and behavioral change.

Threat. Threat comprises two variables: severity and susceptibility. In order for the fear appeal to have any effect, the individual must perceive that a threat exists - one that is significant and relevant. Importantly, there is a distinction between message characteristics that express these components and the perception of them by individual message recipients. How a person evaluates the threat is determined by how severe they perceive the threat to be and how personally susceptible they think they are.

Severity. In EPPM, severity of the threat is the magnitude of detrimental consequences associated with the risk - the potential result of taking no action. As applied in EPPM, severity refers to message characteristics designed to convey this magnitude, while perceived severity is the attitude held by the intended audience. In a health-related example, campaigns aimed at the risk of smoking might emphasize the severity of outcomes such as lung cancer. In a public policy example, campaigns about climate change have emphasized the severity of extreme weather events ( $\mathrm{Li}, 2014)$. 
Susceptibility. Susceptibility is the personal relevance of the threat, or the perceived likelihood that these consequences will be experienced by the individual message recipient. For example, someone who smokes cigarettes infrequently may perceive that their health risk is lower than a heavy smoker (low perceived susceptibility), and so messages targeted at this user may emphasize their susceptibility. In a study about perceptions of climate change, $\mathrm{Li}$ (2014) manipulated perceived susceptibility by using news stories about either weather events in the country or in a remote part of the world.

Efficacy. With its origins in Bandura's (1986) Social Cognitive Theory, efficacy in risk communication refers to agentic cognitive appraisals. Witte's (1992) original model identified two efficacy dimensions: self-efficacy and response efficacy. Selfefficacy is a belief about personal agency — that is, the extent to which the individual views themself as capable of producing desired effects and preventing undesired ones (Bandura, 2000). Response efficacy is the confidence that the recommended behavior or solution will adequately address the threat. Both dimensions have been shown to affect attitudes and behaviors for risks such as pandemics (Barnett et al., 2009), sexually transmitted diseases (Hong, 2011); and climate change (Feldman \& Hart, 2014; Hart \& Feldman, 2016). Previous research found that combining response efficacy information with internal and external political efficacy information in messages about climate change increased intended political participation through increased hope (Feldman \& Hart, 2016).

\section{Policy Issues}

Consistent with the findings of risk communication practitioners, observations about the individualized politics of actualizing citizens raises the possibility that 
motivations to participate should be examined at the issue level (Bennett, 2008). To test the utility of this approach, I have selected two policy areas that have been framed in terms of risk to individual and social well-being: climate change and social security.

\section{Climate Change}

Despite widespread agreement among the scientific and academic communities that climate change is occurring, largely human-caused, and poses dire risks to the planet and humanity (Dryzek, Norgaard, \& Schlosberg, 2011), there is a persistent lack of consensus among partisans and policymakers in the United States (Hart \& Feldman, 2016; McCright \& Dunlap, 2003). While much of the doubt is sowed intentionally by special interests (Brulle, 2019; Dunlap \& McCright, 2011), there are good reasons for the public to experience mixed perceptions and understandings of the risks associated with climate change (Jamieson, 2011). Much of the impact of climate change is not visible or imminent to many people, particularly in the United States where wealth and infrastructure shield us from the consequences of our contribution (Jamieson, 2011; Mendelsohn, Dinar, \& Williams, 2006). In addition to uncertainty over the causes and implications of climate change, its rapid politicization has caused marked disagreements over what, if anything, should be done to address it at the policy level (Dunlap \& McCright, 2011). While liberals and Democrats in government have proposed sweeping measures to reduce emissions and invest in sustainable industry (e.g. H.R. 109), conservatives and Republicans largely downplay the severity of climate change and oppose policies designed to address it (Gerrard, 2016; Moser \& Dilling, 2011).

Climate change is a threat multiplier (Abrahams, 2019), meaning that its consequences are likely to add irreparable strain to existing fault lines and weaknesses in 
a society. Though outcome projections vary widely and depend on myriad factors, scientists and researchers acknowledge that the United States is not invulnerable to deleterious consequences such as drought, extreme weather events, and sea level rise, which could result in food insecurity and significant internal migration (Feng, Oppenheimer, \& Schlenker, 2012; Smith \& Gregory, 2013). The severity of potential outcomes is known to scientists and reported by news media, but content analyses have found that liberal-leaning outlets are more likely to include this information than conservative-leaning outlets. In addition, though both liberal and conservative outlets habitually divorce threat and efficacy information in their coverage of climate change, conservative outlets are more likely to include negative efficacy information (Feldman, Hart, \& Milosevic, 2017). Based on predictions of the EPPM, differential perceptions of threat and efficacy could have impacts on behavioral reactions. Given that climate change is such a controversial policy issue, those reactions will arguably be reflected in political participation. Therefore, I propose the following hypothesis:

H2: Severity, susceptibility, self-efficacy, and response efficacy perceptions for climate change predicts variance in political participation.

\section{Social Security}

Social Security is a government-run program that supports the economic security of elderly citizens. It is funded by working citizens, who pay into the program with the expectation that they will one day be able to draw from it themselves. Social security has long been a popular program with a diverse base of support and is often cited as a policy priority by liberal, moderate, and conservative citizens (Pew Research Center, 2019;

Sherman, 1989; Yang \& Barrett, 2006). In recent years, however, confidence in the 
solvency of the program has decreased, with an increasing number of peopleparticularly young people - doubting they will be able to rely on social security when they retire (Parker, Morin, \& Horowitz, 2019). These concerns are not unfounded. The Social Security Administration (SSA), part of the Old-Age, Survivors, and Disability Insurance (OASDI) program, has long warned that program costs are due to exceed income - an eventuality that has come to pass, as confirmed in their 2019 Annual Report (SSA, 2019). For decades, politicians have been discussing reforms to social security. Like climate change, the depletion of the funds has not been unanimously regarded as a crisis (Yang \& Barrett, 2006) and proposals to address the problem vary. While Republican politicians have largely favored constriction of the program, Democrats have pushed for expansions paid for through taxes on high-income earners (Biden, 2020; Yang \& Barrett, 2006).

Despite the importance of the program to a large number of citizens, little research has been done on the antecedents of public attitudes toward social security and social security reform (Yang \& Barrett, 2006). Consistent with results of public opinion research (e.g. Pew Research Center, 2019), Yang and Barrett (2006) determine that the effect of political ideology on social security attitudes is insignificant. Instead they note that self-interest, or social structural position, has a much stronger effect, with citizens who are less secure being more likely to favor protection of social security as a policy priority. Therefore, I offer the following hypothesis:

H3: Severity, susceptibility, self-efficacy, and response efficacy perceptions for social security predicts political participation.

\section{Affective Polarization}


The political application of fear appeals extends beyond policy issues to frame political actors and parties as a risk. There is a growing concern over the widening gap between the Democratic and Republican parties in the United States. In addition to markedly divergent political perspectives, members of the two parties increasingly report a rancorous dislike for and distrust of one another (Dias \& Lelkes, 2021; Iyengar, Lelkes, Levendusky, Malhotra, \& Westwood, 2019; Levendusky, 2013). The growing disparity between how partisans feel about the in-party and the out-party is known as affective polarization.

Research on affective polarization suggests that it may be driven by ideological polarization (Dias \& Lelkes, 2021; Iyengar et al., 2019) and partisan media exposure (Iyengar et al., 2019; Levendusky, 2013). While a degree of disagreement over policy and cultural issues is an inherent part of our political system, the way these differences are communicated by partisan sources drives the negative affective response. Levendusky (2013) describes partisan media as opinionated media, helping in-party members make sense of political information through a shared ideology. He notes, however, that partisan media often achieves this not just through explaining why the in-party is right, but by focusing on why the out-party is wrong. This pronounced partisan slant leads viewers to like and trust the out-party less and show less support for bipartisanship.

This effect is mirrored by the rhetoric of politicians, who have increasingly emphasized the danger posed by their political opponents (Badger, 2020; Ball, 2016). During the 2020 presidential election, for example, President Donald Trump was repeatedly portrayed by liberals as "dangerous" (e.g. Cilliza, 2020) while conservatives insisted that Democrats constituted the primary threat facing the country (e.g. Costa, 
Weigel, Sonmez, \& Wagner, 2020). Public opinion polling during the campaign found that a majority of voters on both sides of the political aisle believe that a victory by the other party would result in "lasting harm to the nation" (Deane \& Gramlich, 2020, para. 12). Given this evidence that political parties and actors are perceived as risks, it is possible that political participation is driven in part by concerns about the agendas of unfavored political parties and candidates. To investigate this, I offer the following hypothesis:

H4: Political polarization and positive and negative perceptions of the Republican and Democratic parties predicts variance in political participation.

To explore whether combining insights from political communication and risk communication can increase understanding of the variance in political participation, I offer the following research questions:

RQ1: Does the addition of EPPM variables (severity, susceptibility, self-efficacy, response efficacy, and collective efficacy) regarding climate change to political variables (political interest, civic duty, internal efficacy, and external efficacy) explain additional variance in political participation?

RQ2: Does the addition of EPPM variables (severity, susceptibility, self-efficacy, response efficacy, and collective efficacy) regarding social security to political variables (political interest, civic duty, internal efficacy, and external efficacy) explain additional variance in political participation?

RQ3: Does the addition of affective polarization variables (polarization, positive and negative perceptions of the Democratic and Republican parties) to political variables 
(political interest, civic duty, internal efficacy, and external efficacy) offer additional predictive power for political participation?

\section{Methods}

\section{Participants}

Participants $(n=240)$ were recruited from the College of Liberal Arts and Sciences at Portland State University. While most professors were able to offer extra credit to their classes in exchange for participation, some were not. IRB approval was obtained for both conditions and two identical versions of the survey were offered, preceded by different informed consent forms to accommodate the two groups. Of the 240 responses, 188 received extra credit and 52 did not. Twenty-two responses were more than $75 \%$ incomplete and so were excluded from analysis. The remaining participants $(n=219)$ were mostly female $(n=122,55.7 \%)$ and white $(n=117,53.4 \%)$, with a median age of $24(M=27.35, S D=8.43)$. A majority of participants were Democrats $(n=115,52.5 \%)$ with liberal economic $(n=142,67.6 \%)$ and social views $(n$ $=169,77.2 \%)$. See Table 1 for more sample characteristics. 
Table 1.

Participant Characteristics

\begin{tabular}{|c|c|c|}
\hline Age & $n$ & $\%$ \\
\hline $18-24$ & 94 & 42.9 \\
\hline $25-34$ & 59 & 26.9 \\
\hline $35-44$ & 17 & 7.8 \\
\hline $45-54$ & 8 & 3.7 \\
\hline 55 and older & 3 & 1.4 \\
\hline Missing & 38 & 17.3 \\
\hline Annual Household Income & $n$ & $\%$ \\
\hline Less than $\$ 10,000$ & 22 & 10.0 \\
\hline$\$ 10,000-\$ 19,999$ & 32 & 14.6 \\
\hline$\$ 20,000-\$ 29,999$ & 34 & 15.5 \\
\hline$\$ 30,000-\$ 39,999$ & 18 & 8.2 \\
\hline$\$ 40,000-\$ 49,999$ & 15 & 6.8 \\
\hline$\$ 50,000-\$ 59,999$ & 21 & 9.6 \\
\hline$\$ 60,000-\$ 69,999$ & 11 & 5.0 \\
\hline$\$ 70,000-\$ 79,999$ & 5 & 2.3 \\
\hline$\$ 80,000-\$ 89,999$ & 7 & 3.2 \\
\hline$\$ 90,000-\$ 99,999$ & 9 & 4.1 \\
\hline$\$ 100,000$ or more & 39 & 17.8 \\
\hline Missing & 6 & 2.7 \\
\hline Race/Ethnicity & $n$ & $\%$ \\
\hline $\begin{array}{l}\text { American Indian or Alaska } \\
\text { Native }\end{array}$ & 4 & 1.8 \\
\hline Asian & 26 & 11.9 \\
\hline Black or African American & 10 & 4.6 \\
\hline Hispanic or Latino & 28 & 12.8 \\
\hline $\begin{array}{l}\text { Native Hawaiian or Pacific } \\
\text { Islander }\end{array}$ & 1 & 0.5 \\
\hline White or Caucasian & 121 & 55.2 \\
\hline Multiracial or Biracial & 15 & 6.8 \\
\hline Prefer not to respond & 14 & 6.4 \\
\hline Gender & $n$ & $\%$ \\
\hline Female & 122 & 55.7 \\
\hline Male & 80 & 36.5 \\
\hline Prefer not to respond & 17 & 7.8 \\
\hline
\end{tabular}

\begin{tabular}{lcc}
\hline Highest Level of Education & $\boldsymbol{n}$ & $\boldsymbol{\%}$ \\
\hline Less than high school & 1 & 0.5 \\
High school graduate or GED & 9 & 4.1 \\
Some college & 79 & 36.1 \\
Associate's (2-year) degree & 87 & 39.7 \\
Bachelor's (4-year) degree & 34 & 15.5 \\
Graduate degree & 9 & 4.1
\end{tabular}

\begin{tabular}{lcc}
\hline Party Affiliation & $\boldsymbol{n}$ & $\boldsymbol{\%}$ \\
\hline Democratic & 115 & 52.5 \\
Republican & 12 & 5.5 \\
Member of Another Party & 24 & 11.0 \\
Unaffiliated & 65 & 29.7 \\
Missing & 3 & 1.4 \\
\hline
\end{tabular}

\begin{tabular}{lcc}
\hline Economic Political Ideology & $\boldsymbol{n}$ & $\boldsymbol{\%}$ \\
\hline Very Liberal & 47 & 21.5
\end{tabular}

Liberal $\quad 5926.9$

Moderately Liberal $\quad 42 \quad 19.2$

Moderate $\quad 42 \quad 19.2$

$\begin{array}{lll}\text { Moderately Conservative } & 18 \quad 8.2\end{array}$

$\begin{array}{lll}\text { Conservative } & 5 & 2.3\end{array}$

$\begin{array}{lll}\text { Very Conservative } & 2 & 0.9\end{array}$

\begin{tabular}{lcc} 
Missing & 4 & 1.8 \\
\hline Social Political Ideology & $\boldsymbol{n}$ & $\boldsymbol{\%}$
\end{tabular}

\begin{tabular}{lll}
\hline Very Liberal & 81 & 37.0
\end{tabular}

Liberal $61 \quad 27.9$

$\begin{array}{lll}\text { Moderately Liberal } & 27 & 12.3\end{array}$

Moderate $\quad 34 \quad 15.5$

Moderately Conservative $\quad 5 \quad 2.3$

$\begin{array}{lll}\text { Conservative } & 6 & 2.7\end{array}$

$\begin{array}{lll}\text { Very Conservative } & 2 & 0.9\end{array}$

\begin{tabular}{lll} 
Missing & 3 & 1.4 \\
\hline
\end{tabular} 


\section{Design}

A survey design measured variables of interest from both political communication and risk communication theories.

\section{Recruitment and Data Collection}

All recruitment was conducted remotely and at the discretion of the professors. Methods varied by class and included a recorded video appeal from the author, a live appeal made in remote classes, and email announcements. All students were directed to a survey link shared electronically either by email or on the class page of the school's learning platform, D2L. Data collection began on February 11, 2021, and concluded on March 12, 2021.

\section{Measures}

Dependent variable. The outcome variable was political participation. Risk communication scholars identify behavioral intention as the strongest predictor of actual behavior (Azjen, 1991; Azjen \& Fishbein, 1977; Glasford, 2008). While some political scholars caution against the use of intention as a reliable measure for electoral participation, direct inquiry into this question using panel data has determined that there is a strong correlation between intended and reported participation (Quintelier \& Blais, 2016). Nevertheless, Quintelier and Blais (2016) also note that the intention-behavior gap is larger for those with higher levels of political interest, education, and civic duty. They caution that reported participation may be a more accurate measure when the goal of a study is to estimate the magnitude of the effect of a set of variables on participation. With this in mind, I measured both actual and intended participation. Two questions measured past participation in (1) presidential and (2) midterm (congressional) elections. 
To capture forms of participation outside of voting, I adapted the measure of participation used in the American National Election Studies (ANES) 2020 Pilot Survey. The original measure asks about participatory behavior in the past 12 months; I instead asked about likelihood of engaging in these behaviors in the upcoming 12 months. The measure included 8 items with a 5-point response scale (extremely unlikely-extremely likely). Sample behaviors include "join in a protest march, rally, or demonstration" and "post a message or comment online about a political issue or campaign." These 8 items were combined with the two voting items and averaged to form a participation variable $(\boldsymbol{\alpha}=$ $.84)$.

\section{Political variables}

Political interest. As recommended by Blais and Daoust (2020) and supported by the findings of Prior (2018), political interest was measured with a single, direct question. Participants rated their level of interest in national politics on a scale from 1 ("not at all interested") to 5 (“extremely interested"). See Table 2 for political variable means and standard deviations.

Political efficacy. Two items each measured internal and external political efficacy, taken from the ANES. Though measurement of political efficacy has been inconsistent in the literature (Chamberlain, 2012; Morrell, 2003), the ANES measure is

often used by researchers in the United States. This measure has changed over the years, which may contribute to the confusion over the optimal way to operationalize the concepts. Correlation was used in place of reliability coefficients for these two-item scales. As both were significant and moderate, new variables were created from the mean of each pair of questions. 
To measure internal political efficacy, participants were asked, "How often do politics and government seem so complicated that you can't really understand what's going on?" and "How well do you understand the important political issues facing our country?" $(r=.47, p<.001)$ with 5-point response scales. To measure external political efficacy, participants were asked the extent to which they agree or disagree with the following statements on a 5-point scale: "People like me don't have any say about what the government does," and "Public officials don't care much what people like me think" $(r=.45, p<.001)$

Civic duty. Following the recommendation of Blais and Galais (2016), a fouritem scale was used to measure civic duty $(\alpha=.73)$. The original study is designed to be given over the phone, with varying response options (0-3 and 0-10), depending on the question. In order to better fit the rest of the present survey, the question wording was adapted to fit an agree-disagree scale. For example, a sample item from the original scale, "How guilty would you feel if you did not vote in an election?" was reworded as "I would feel guilty if I did note vote in an election".

Table 2.

Political variables

\begin{tabular}{lcccccc}
\hline Variable & $n$ & $M$ & $M d n$ & $S D$ & $\alpha$ & $r$ \\
\hline Political participation (Outcome) & 219 & 2.96 & 3.0 & 0.92 & .84 & - \\
\hline Political interest & 218 & 3.43 & 3.0 & 1.12 & - & - \\
Internal political efficacy & 219 & 3.15 & 3.0 & 0.81 & - & $.47^{* *}$ \\
External political efficacy & 219 & 2.85 & 3.0 & 0.97 & - & $.45^{* *}$ \\
Civic duty & 219 & 3.61 & 3.8 & 0.97 & .73 & - \\
\hline
\end{tabular}

**Correlation between scale items is significant at the .01 level

\section{Risk perception variables}


Policy issues. Risk perceptions were measured for each of the two policy issuesclimate change and social security. Variables from the extended parallel process model (perceived severity, susceptibility, and response efficacy) were measured with an adaptation of Witte, Cameron, McKeon, and Burkowitz's (1996) Risk Behavior Diagnosis Scale. These variables were measured with three questions each on a 5-point agree-disagree scale. Sample questions included "Climate change is a significant threat" (severity, $\mathrm{CC} \alpha=.97, \mathrm{SS} \alpha=.96$ ), "It is likely that I will be affected by extreme weather events as a result of climate change" (susceptibility, $\operatorname{CC} \alpha=.79, \operatorname{SS} \alpha=.76$ ), and "Political participation is an effective way to address climate change" (response efficacy, $\mathrm{CC} \alpha=.83$, SS $\alpha=.81)$. In order to mitigate any priming effects, the order of these two policy blocks was randomized. See Table 3 for means and scale reliabilities.

Political self-efficacy. The fourth variable in the extended parallel process model is self-efficacy. A measure of political self-efficacy was taken from Caprara, Vecchione, Capanna, and Mebane (2009). This 10-item, 5-point scale asks participants how capable they feel to perform a range of behaviors related to political participation (not at all capable-completely capable). Sample items include "State your own political opinion openly, even in clearly hostile settings" and "Use the means you have as a citizen to critically monitor the actions of your political representatives." These items were combined $(\alpha=.92)$, with the mean representing self-efficacy in both the climate change and social security models. 
Table 3.

Risk perception variables

\begin{tabular}{lccccc}
\hline Variable & $n$ & $M$ & $M d n$ & $S D$ & $\alpha$ \\
\hline Climate change severity & 218 & 6.57 & 7.0 & 0.83 & .97 \\
Climate change susceptibility & 218 & 5.07 & 5.0 & 1.34 & .79 \\
Climate change response efficacy & 218 & 5.62 & 6.0 & 1.28 & .83 \\
\hline Social security severity & 219 & 5.81 & 6.0 & 1.23 & .96 \\
Social security susceptibility & 219 & 5.17 & 5.0 & 1.22 & .76 \\
Social security response efficacy & 218 & 5.07 & 5.0 & 1.18 & .81 \\
\hline Political self-efficacy (5-point scale) & 219 & 2.69 & 2.6 & 0.92 & .92 \\
\hline
\end{tabular}

Affective polarization. A measure of polarization was taken from Druckman and Levendusky (2019), using two feeling thermometers. Participants were asked to rate their feelings toward the Republican and Democratic Parties on scales ranging from 0 (cold/unfavorable) to 100 (warm/favorable). The score for the Democratic feeling thermometer was subtracted from the Republican feeling thermometer, resulting in a raw score for polarization. Regardless of sign, those who felt similarly about both parties had a lower score. An interval scale was then constructed from this initial score, creating five categories from 1 ( -20 to 0 or 0 to 20$)$ to 5 ( -100 to -81 or 81 to 100$)$, with higher scores indicating more polarization.

Trait ratings. In order to gain a more nuanced understanding of participants' perceptions of each party, a scale adapted from Druckman and Levendusky (2019) was included to assess the traits they associate with the Republican and Democratic party. Participants were asked how well a list of ten traits (five positive and five negative) describe each party. To avoid priming effects, the order in which the parties were presented was randomized. Druckman and Levendusky’s (2019) original instrument contained eight traits (five positive and three negative). In the present study, two 
additional negative traits were added: dangerous and frightening. These additions were intended to better capture whether participants perceive the two parties as potential risks. Positive and negative trait ratings were created for each party by combining the five items. See Table 4 for means and scale reliabilities.

Table 4.

Affective polarization variables

\begin{tabular}{lccccc}
\hline Variable & $n$ & $M$ & $M d n$ & $S D$ & $\alpha$ \\
\hline Polarization & 200 & 2.90 & 3.0 & 1.30 & - \\
\hline Positive traits Republican Party & 215 & 2.16 & 2.0 & 0.80 & .75 \\
Negative traits Republican Party & 215 & 3.89 & 4.0 & 0.93 & .86 \\
\hline Positive traits Democratic Party & 215 & 3.23 & 3.2 & 1.23 & .77 \\
Negative traits Democratic Party & 213 & 2.45 & 2.2 & 1.18 & .88 \\
\hline
\end{tabular}

\section{Results}

A multiple linear regression was used to test $\mathrm{H} 1$. The model containing variables of interest in political communication explained a statistically significant portion of the variance in political participation, $F(4,213)=30.83, \mathrm{p}<.001, R_{\text {Adjusted }}=.36$. Political interest $(\beta=.51, t / 213=8.11, p<.001)$ and civic duty $(\beta=.21, t / 213=3.55, p=.001)$ explain a significant portion of the variance in political participation. Contrary to previous work, neither internal $(\beta=.02, t / 213=0.34, p=.736)$ nor external $(\beta=.04$, $t / 213=0.71, p=.478)$ political efficacy explain significant portions of the variance in participation. Therefore H1 was partially supported.

Two multiple linear regressions were used to test whether risk communication variables explain variance in political participation, based on perceptions of two different policy issues. The climate change model explained a statistically significant portion of the variance in political participation, $F(4,213)=24.75, \mathrm{p}<.001, R^{2}{ }_{\text {Adjusted }}=.31$. Perceived 
severity of climate change $(\beta=.18, p<.01)$, political self-efficacy $(\beta=.33, p<.001)$, and response efficacy $(\beta=.18, p=.01)$ explained a significant portion of the variance in political participation. Perceived susceptibility to climate change effects was not a significant predictor of participation, therefore $\mathrm{H} 2$ was partially supported. See Table 5 for a full reporting of the variables in each model.

The social security model explained a statistically significant portion of the variance in political participation, $F(4,213)=17.01, \mathrm{p}<.001, R_{\text {Adjusted }}=.23$, carried only by political self-efficacy, $\beta=.41, p<.001$. Perceived severity of social security insolvency, perceived susceptibility to the effects of social security insolvency, and social security response efficacy were not significant predictors of political participation, therefore H3 was partially supported.

A multiple regression was used to test whether perceptions of political parties explain variance in political participation. The model explained a statistically significant portion of the variance in participation, $F(5,190)=11.39, \mathrm{p}<.001, R_{{ }_{\text {Adjusted }}}=.21$. While the model included polarization and positive and negative perceptions of both parties, only negative perceptions of the Republican Party was significant, $\beta=.37, p<.001$, therefore H4 was partially supported. 
Table 5.

Results of Multiple Regression Analyses Predicting Political Participation

\begin{tabular}{|c|c|c|c|c|c|c|}
\hline & $\beta$ & $p$ & $F$ & $d f$ & $p$ & $R_{{ }_{A}}$ \\
\hline H1 Overall model & & & 30.83 & 4,213 & $<.001$ & .36 \\
\hline Political interest & .51 & $<.001$ & & & & \\
\hline Internal political efficacy & .02 & .736 & & & & \\
\hline External political efficacy & .04 & .478 & & & & \\
\hline Civic duty & .21 & $<.001$ & & & & \\
\hline H2 Overall model & & & 24.75 & 4,213 & $<.001$ & .31 \\
\hline Climate change severity & .18 & .009 & & & & \\
\hline Climate change susceptibility & .08 & .197 & & & & \\
\hline Political self-efficacy & .33 & $<.001$ & & & & \\
\hline Climate change response efficacy & .18 & .011 & & & & \\
\hline H3 Overall model & & & 17.01 & 4,213 & $<.001$ & .23 \\
\hline Social security severity & .06 & .407 & & & & \\
\hline Social security susceptibility & .10 & .095 & & & & \\
\hline Political self-efficacy & .41 & $<.001$ & & & & \\
\hline Social security response efficacy & .10 & .199 & & & & \\
\hline H4 Overall model & & & 11.39 & 5,190 & $<.001$ & .21 \\
\hline Polarization & .13 & .116 & & & & \\
\hline Positive perception Democratic Party & .06 & .492 & & & & \\
\hline Negative perception Democratic Party & .01 & .897 & & & & \\
\hline Positive perception Republican Party & -.05 & .506 & & & & \\
\hline Negative perception Republican Party & .37 & $<.001$ & & & & \\
\hline
\end{tabular}

Note: Significant variables are emphasized in bold.

Two research questions were also posed, asking whether policy-centered risk perception variables could explain additional variance in participation when controlling for political variables. To investigate these questions, two hierarchical multiple regressions were conducted with political participation as the dependent variable.

Political interest, civic duty, internal and external political efficacy entered simultaneously in the first block (Model 1), and risk perception variables for each policy issue were added in the second blocks. Model one predicted a significant portion of the 
variance in participation in both the climate change and social security models, $F(4,212)$ $=30.65, p<.001, R^{2}=.35$. Adding risk and efficacy variables for climate change in the second model further contributed to the explanation of variance in participation, $F(4$, $208)=6.47, p<.001, R_{A}^{2}=.42$. Climate change response efficacy $(\beta=.17, p=.007)$ and political self-efficacy $(\beta=.13, p=.046)$ contributed significantly to the model, while perceived severity and susceptibility for climate change did not.

Adding risk and efficacy perceptions for social security to political variables of interest in the third model also contributed further to the explanation of variance in participation, $F(4,208)=3.91, \mathrm{p}=.004, R^{2}=.39$. However, of the four variables, only political self-efficacy $(\beta=.22, p=.001)$ was significant.

Table 6.

Summary of Hierarchical Multiple Regression Analyses, RQ1 and RQ2

\begin{tabular}{|c|c|c|c|c|c|c|}
\hline & \multicolumn{2}{|c|}{ Model 1} & \multicolumn{2}{|c|}{ Model 2} & \multicolumn{2}{|c|}{ Model 3} \\
\hline & $\beta$ & $p$ & $\beta$ & $p$ & $\beta$ & $p$ \\
\hline Political interest & .51 & $<.001$ & .36 & $<.001$ & .41 & $<.001$ \\
\hline Civic duty & .21 & .001 & .15 & .007 & .18 & .002 \\
\hline Internal political efficacy & .02 & .737 & .01 & .821 & -.01 & .923 \\
\hline External political efficacy & .04 & .479 & .01 & .895 & .33 & .574 \\
\hline Climate change severity & & & .07 & .245 & & \\
\hline Climate change susceptibility & & & .05 & .370 & & \\
\hline $\begin{array}{l}\text { Climate change response } \\
\text { efficacy }\end{array}$ & & & .17 & .007 & & \\
\hline Political self-efficacy & & & .13 & .046 & .22 & .001 \\
\hline Social Security severity & & & & & -.03 & .662 \\
\hline Social Security susceptibility & & & & & .05 & .332 \\
\hline $\begin{array}{l}\text { Social Security response } \\
\text { efficacy }\end{array}$ & & & & & .06 & .401 \\
\hline Model Summary & $\begin{array}{r}F(4,2 \\
p \\
R\end{array}$ & $\begin{array}{l}=30.65 \\
01 \\
.35\end{array}$ & $\begin{array}{r}F(4,2 \\
p \\
R\end{array}$ & $\begin{array}{l}=6.47 \\
01 \\
.42\end{array}$ & $\begin{array}{r}F(4,20 \\
p \\
R^{2}\end{array}$ & $\begin{array}{l}=3.91 \\
04 \\
39\end{array}$ \\
\hline
\end{tabular}

Note: Significant variables are emphasized in bold. 
A third research question asked whether perceptions of political parties added to the explanatory power of the political variables. To investigate this question, a hierarchical multiple regression was conducted with political interest, civic duty, internal and external political efficacy in the first block (Model 1; F/4,191 $=27.61, p<.001, R_{A}^{2_{A}}=$ .35) and polarization, positive perceptions of each party and negative perceptions of each party in the second block. The resulting fourth model contributed further to the explanation of variance in participation, $F(5,186)=4.03, \mathrm{p}=.002, R_{A}=.40$. Of the affective variables, only negative perceptions of the Republican Party $(\beta=.26, p<.001)$ was significant.

\section{Table 7.}

Summary of Hierarchical Multiple Regression Analyses, RQ3

\begin{tabular}{|c|c|c|c|c|}
\hline & \multicolumn{2}{|c|}{ Model 1} & \multicolumn{2}{|c|}{ Model 4} \\
\hline & $\beta$ & $p$ & $\beta$ & $p$ \\
\hline Political interest & .51 & $<.001$ & .44 & $<.001$ \\
\hline Civic duty & .21 & .001 & .16 & .009 \\
\hline Internal political efficacy & .02 & .750 & .04 & .536 \\
\hline External political efficacy & .04 & .502 & .01 & .931 \\
\hline Polarization & & & .08 & .243 \\
\hline Positive perceptions of the Democratic Party & & & -.12 & .168 \\
\hline Negative perceptions of the Democratic Party & & & -.12 & .175 \\
\hline Positive perceptions of the Republican Party & & & .08 & .299 \\
\hline Negative perceptions of the Republican Party & & & .26 & $<.001$ \\
\hline Model Summary & \multicolumn{2}{|c|}{$\begin{array}{c}F(4,191)=27.61 \\
p<.001 \\
R_{A}^{2_{A}}=.35\end{array}$} & \multicolumn{2}{|c|}{$\begin{array}{c}F(5,186)=4.03 \\
p=.002 \\
R_{A}^{2}=.40\end{array}$} \\
\hline
\end{tabular}

Note: Significant variables are emphasized in bold. 


\section{Discussion}

The results of this study demonstrate that risk perceptions could help expand our understanding of political participation. The participants in the present study reflect a young, liberal demographic that aligns in many ways with Bennett's (2008) idea of the actualizing citizen. Understanding the perceptions and behavior of this group offers valuable insight into the changing trends in political participation. A key limitation of this study, however, is the use of a convenience sample. While participants in the present study largely reflect a demographic that is becoming more active in politics (Cilluffo \& Fry, 2019; Fabina, 2021), probability sampling from a larger population is needed to draw more firm conclusions. What this study can offer is a glimpse into possible fruitful avenues of inquiry.

\section{Political Variables}

Of the four political variables tested, political interest contributes most to the explanation of the variance in participation, followed by civic duty. This aligns with previous research that suggests that interest is a necessary precursor to participation (Blais, 2000; Blais \& Daoust, 2020; Brady, Verba, \& Schlozman, 1995; Prior, 2010). Civic duty has long been associated with electoral participation (Blais, 2000; Riker and Oldeshook, 1968) but recent trends have caused some scholars to question how well it accounts for the political behavior of younger citizens (Bennett, 2008; Bennett, Wells, \& Rank, 2009). The present study affirms its continued importance for this group.

Contrary to previous findings, neither internal nor external political efficacy were significantly associated with political participation in this study. This lack of impact may be due to the anemic scales. Consistent with other recent research in the United States, 
the present study used the measurement of political efficacy from the American National Election Studies (ANES). Because these measures include only two questions each to measure internal and external efficacy, internal reliability cannot be established. Though the correlations between items were significant and moderate, future research should return to the issues surrounding measurement of political efficacy. Given the persistent significance of political self-efficacy in the models, the role of efficacy in political participation should not be overlooked.

\section{Policy Risk Perceptions}

Political self-efficacy was included as one of four variables in the risk perception models and explained a significant portion of the variance in participation in all of the models to which it was added. The other variables in these two models were issuespecific measurements of participants' perceptions of climate change and social security. The Extended Parallel Process Model predicts adoption of the recommended behavior when both threat and efficacy perceptions are high. Though the present study is crosssectional and cannot establish a causal link, these results suggest that the EPPM could be applied to political behavior.

There was a notable difference between the two policy issue models. In the climate change model, perceived severity, perceived response efficacy, and political selfefficacy were significantly associated with participation; in the social security model the only significant variable was political self-efficacy, which was not issue-specific. It appears that risk perceptions of social security did not impact political participation in the present study. This is likely due to the life stage of the participants. While protecting social security for use by future generations of Americans generally garners widespread 
support (Dunlap \& McCright, 2011), it may not be a relevant concern for college students. It is also possible that issue-based participation is only significant for polarized issues. While climate change elicits strong reactions from partisans on both sides of the political spectrum, social security is a less controversial issue (Dunlap \& McCright, 2011; Hart \& Feldman, 2016; Jamieson, 2011; Pew Research Center, 2019). This may impact the degree to which it influences participation among political partisans. Future research should investigate whether salient issues for different populations contribute differently to their political behaviors.

When the issue-specific risk perception variables were added to the political variables, climate change response efficacy was retained in the final model but not perceived severity nor perceived susceptibility. This suggests that efficacy perceptions may drive participation more than the perceived importance or personal relevance of even salient policy issues.

\section{Party Risk Perceptions}

Record voter turnout in the 2018 midterm and 2020 presidential elections reversed a decades-long downward trend in electoral participation (Campbell, 2006; Norris, 2015; Persily \& Stewart III, 2021). Public discourse during the campaigns suggested that a driving force in electoral participation might be perceptions of a political party as a risk. That is, an individual may be more motivated to vote in order to prevent an unfavorable party from winning than to advance a favorable party. Rhetoric from both Republicans and Democrats leading up to the 2020 presidential election framed their political opponents as dangerous and frightening, and as a risk to the wellbeing of the 
country (e.g. Badger, 2020; Ball, 2016; Cilliza, 2020; Costa, Weigel, Sonmez, \& Wagner, 2020). It is possible that these messages are related to the record-breaking turnout.

Of the affective polarization variables examined in the present study, negative perceptions of the Republican Party explained the most variance in political participation. By itself and coupled with political interest and civic duty, affective polarization —or the magnitude of the difference between one's feelings toward the Democratic and Republican Parties - did explain a significant portion of the variance in participation but the effect disappeared when other affective variables were added. In the present sample, it seems that a driving affective force behind participation is negative perceptions of the Republican Party. Because the participants in this study overwhelmingly leaned toward a liberal political ideology and self-identified as aligning with the Democratic Party, these results are perhaps not surprising. Future research should investigate whether the same trends hold among more conservative populations. A key limitation of this study is that the full complement of EPPM variables was not measured for affective polarization. While negative perceptions of the parties could represent perceived threat, future research should measure feelings of susceptibility to the "threat" of the outparty and should include efficacy perceptions.

\section{Implications}

Taken together, these findings add to the literature in three ways. First, they affirm the conclusions of previous research in political communication (Blais, 2000; Blais \& Daoust, 2020; Brady, Verba, \& Schlozman, 1995; Prior, 2010). Political interest and civic duty continue to be robustly associated with political participation. While some have expressed concerns that younger citizens in particular may not be as motivated by 
civic duty, the present study suggests that it remains a relevant factor for participation. Future research should continue to examine determinants of participation for younger generations, and to support efforts to foster interest and civic duty in future generations of citizens.

Second, the present study highlights the importance of self-efficacy for political participation and calls for a renewed investigation into the conceptualization and operationalization of the construct in political communication. While efficacy has long been theorized to play a role in political participation (Campbell, Gurin, \& Miller, 1954; Craig, 1979; Niemi, Craig, \& Mattei, 1991), the performance of internal and (particularly) external political efficacy has been unstable in prior research (Acock \& Clarke, 1990; Caprara et al., 2009; Chamberlain, 2012). This may be due to inconsistent measurement (Caprara et al., 2009; Chamberlain, 2012; Craig, Niemi, \& Silver, 1990; Morrell, 2003; Niemi, Craig, \& Mattei, 1991), which limits the ability to meaningfully compare results across studies.

This instability may also suggest that the evolution of the concept of efficacy within the field has not kept pace with the development in other subfields such as risk communication. Caprara et al. (2009) argue for a return to Bandura's Social Cognitive Theory to revitalize the concept. They use SCT to create a more robust measure of political efficacy which asks whether participants feel capable of performing different political behaviors. This aligns conceptually with internal efficacy, though some items on the scale do incorporate elements of external efficacy. In the present study, their measure of political self-efficacy was a significant predictor of participation in the linear models and was retained in the stepwise models, while internal and external efficacy were not. 
The next best efficacy measure to predict political participation in the present study was climate change response efficacy. Items on this response efficacy scale asked whether participants believed that government action could make a difference for climate change. This aligns more clearly with external political efficacy. It is possible that the original ideas behind internal and external efficacy are still relevant, but the current measurement instrument used in political communication has been diluted beyond usefulness. Future research should take up this persistent issue, and may benefit from combining insights from risk communication theory to fine tune the application of efficacy for politics.

Third, this study extends recent work on affective polarization that suggests that participation could be motivated by fear of the outparty. While this indicates that affective polarization has the potential to mobilize partisans (Stapleton, 2020), the cost likely outweighs any benefit. Affective polarization is a growing concern among political scholars, with projected deleterious consequences including decreased support for bipartisanship (Levendusky, 2013), increased proliferation and acceptance of misinformation (Garrett, Long, \& Jeong, 2019), and non-political conflict among citizens (Iyengar et al., 2019). In the present study negative perceptions of the Republican Party emerged as the strongest affective predictor of participation, neutralizing the effect of affective polarization. In other words, the degree of difference between in-party and outparty evaluations was less important than the strength of negative out-party perceptions. While this lopsided result was likely due to the large portion of the sample that aligned with liberal politics and the Democratic Party, future work should examine whether these results are true for other populations, and should explore the relationship between negative evaluations of the outparty and other important variables. 


\section{Conclusion}

This study draws on concepts from political and risk communication to inform our understanding of what motivates people to be politically active. Inspired by concerns that traditional models of participation do not perform as well among younger and more diverse populations (e.g. Bennett, 2008), alternate variables are considered including risk perceptions surrounding policy issues and political parties. Results show that established political variables such as political interest and civic duty remain strongly associated with participation, while offering support for several new variables of interest from the risk communication literature. The present study explored risk and efficacy perceptions for two policy issues, as well as political parties as a potential risk. Results show that threat and efficacy perceptions for climate change and negative perceptions of the Republican Party explained additional variance in political participation when added to known predictors of participation. As scholars and practitioners look for factors that help explain recent reversals in participation trends, risk communication offers perspectives worth exploring. Bennett (2008) observes that our increasingly network-based society may herald a shift to participatory behavior that aligns with or reflects individual identity and self-interest. By exploring the contribution of individuals' threat and efficacy perceptions to explanations of variance in political participation, this study brings attention to the worth of risk. 
References

Abrahams, D. (2019). From discourse to policy: US policy communities' perceptions of and approaches to climate change and security. Conflict, Security \& Development, 19(4), 323-345. https://doi.org/10.1080/14678802.2019.1637080.

Abramson, P. R., \& Aldrich, J. H. (1982). The decline of electoral participation in America. The American political science review, 502-521.

Acock, A. C., \& Clarke, H. D. (1990). Alternative measures of political efficacy: Models and means. Quality and Quantity, 24(1), 87-105.

Ajzen, I. (1991). The theory of planned behavior. Organizational behavior and human decision processes, 50, 179-211.

Ajzen, I., \& Fishbein, M. (1977). Attitude-behavior relations: A theoretical analysis and review of empirical research. Psychological bulletin, 84(5), 888-918. doi: 10.1037/0033-2909.84.5.888

Badger, E. (2020, November 1). Americans Are Afraid. Not for Themselves, but for the Country. NYT.com. https:/www.nytimes.com/2020/11/01/upshot/electiondemocracy-fear-americans.html

Ball, M. (2016, September 2). Donald Trump and the Politics of Fear. TheAtlantic.com. https://www.theatlantic.com/politics/archive/2016/09/donald-trump-and-thepolitics-of-fear/498116/

Bandura, A. (1986) Social foundations of thought and action: A social cognitive theory. Englewood Cliffs, NJ: PrenticeHall.

Bandura, A. (2000). Exercise of human agency through collective efficacy. Current directions in psychological science, 9(3), 75-78. 
Bandura, A. (2001). Social cognitive theory: An agentic perspective. Annual review of psychology, 52(1), 1-26.

Bandura, A. (2004). Social cognitive theory for personal and social change by enabling media. In A. Singhal, M. J. Cody, E. M. Rogers, \& M. Sabido (Eds.), Entertainment education and social change: History, research, and practice (2nd ed., pp. 75-96). New York: Routledge

Barnett, D. J., Balicer, R. D., Thompson, C. B., Storey, J. D., Omer, S. B., Semon, N. L., ... \& Norbin, J. A. (2009). Assessment of local public health workers' willingness to respond to pandemic influenza through application of the extended parallel process model. PloS one, 4(7), e6365.

Barroso, A. (2020). Gen Z eligible voters reflect the growing racial and ethnic diversity of U.S. electorate. https://www.pewresearch.org/fact-tank/2020/09/23/gen-zeligible-voters-reflect-the-growing-racial-and-ethnic-diversity-of-u-s-electorate/

Bene, M. (2020). Does context matter? A cross-country investigation of the effects of the media context on external and internal political efficacy. International Journal of Comparative Sociology, 1-23. 0020715220930065.

Bennett, W. L. (2008). Changing Citizenship in the Digital Age. In W. L. Bennett (Ed.) Civic Life Online: Learning How Digital Media Can Engage Youth. The John D. and Catherine T. MacArthur Foundation Series on Digital Media and Learning, (pp. 1-24). Cambridge, MA: The MIT Press.

doi:10.1162/dmal.9780262524827.001

Bennett, W. L., \& Iyengar, S. (2008). A new era of minimal effects? The changing foundations of political communication. Journal of communication, 58(4), 707- 
731.

Bennett, W. L., Wells, C., \& Rank, A. (2009). Young citizens and civic learning: Two paradigms of citizenship in the digital age. Citizenship studies, 13(2), 105-120.

Best, S. J., \& Krueger, B. S. (2005). Analyzing the representativeness of Internet political participation. Political Behavior, 27(2), 183-216.

Biden, J. (2020). Joe Biden's Plan for Older Americans. Joe Biden for President. https://joebiden.com/older-americans/

Blais, A., \& Daoust, J. F. (2020). The Motivation to Vote: Explaining Electoral Participation. UBC Press.

Blais, A., \& Galais, C. (2016). Measuring the civic duty to vote: A proposal. Electoral Studies, 41, 60-69. https://doi.org/10.1016/j.electstud.2015.11.003

Brader, T. (2006). Campaigning for hearts and minds: How emotional appeals in political ads work. University of Chicago Press.

Brady, H. E., Verba, S., \& Schlozman, K. L. (1995). Beyond SES: A resource model of political participation. American Political Science Review, 89(2), 271-294.

Brulle, R. J. (2019). Networks of opposition: a structural analysis of US climate change countermovement coalitions 1989-2015. Sociological Inquiry, 20, 1-22. https://doi.org/10.1111/soin.12333.

Campbell. (2006). Why we vote: How schools and communities shape our civic life. Princeton, NJ :: Princeton University Press.

Campbell, A., Gurin, G., \& Miller, W. E. (1954). The voter decides. Row, Peterson, and Co..

Caprara, G. V., Vecchione, M., Capanna, C., \& Mebane, M. (2009). Perceived political 
self-efficacy: Theory, assessment, and applications. European Journal of Social Psychology, 39(6), 1002-1020.

Chamberlain, A. (2012). A time-series analysis of external efficacy. Public Opinion Quarterly, 76(1), 117-130.

Cilliza, C. (2020, August 21). This is one of the most dangerous things Donald Trump has done as president. CNN.com. https://www.cnn.com/2020/08/20/politics/donald-trump-qanon

Cilluffo, A., \& Fry, R. (2019, May 29). Gen Z, Millennials and Gen X outvoted older generations in 2018 midterms. Pew Research Center. https://www.pewresearch.org/fact-tank/2019/05/29/gen-z-millennials-and-gen-Xoutvoted-older-generations-in-2018-midterms/

Costa, R., Weigel, D., Sonmez, F., \& Wagner, J. (2020, August 24). Republican convention speakers share dark vision of Democrats and praise Trump's character. WashingtonPost.com.

https://www.washingtonpost.com/elections/2020/08/24/republican-nationalconvention-live-updates/

Craig, S. C. (1979). Efficacy, trust, and political behavior: An attempt to resolve a lingering conceptual dilemma. American Politics Quarterly, 7(2), 225-239.

Craig, S. C. (1980). The mobilization of political discontent. Political Behavior, 2(2), 189-209.

Craig, S. C., Niemi, R. G., \& Silver, G. E. (1990). Political efficacy and trust: A report on the NES pilot study items. Political behavior, 12(3), 289-314.

Cryderman, J., \& Arceneaux, K. (2010). Does fear motivate critical evaluations of 
political arguments? Emotion and dual-processing models of persuasion.

Deane, C. \& Gramlich, J. (2020, November 6). 2020 election reveals two broad voting coalitions fundamentally at odds. Pew Research Center. https://www.pewresearch.org/fact-tank/2020/11/06/2020-election-reveals-twobroad-voting-coalitions-fundamentally-at-odds/

Delli Carpini, M. X. (2000). Gen. com: Youth, civic engagement, and the new information environment. Political Communication, 17(4), 341-349.

Dias, N., \& Lelkes, Y. (2021, April 19). Nature of Affective Polarization. Retrieved from osf.io/458tc

Downs, A. (1957). An economic theory of political action in a democracy. Journal of Political Economy, 65(2), 135-150.

Druckman, J. N., \& Levendusky, M. S. (2019). What Do We Measure When We Measure Affective Polarization? Public Opinion Quarterly, 83(1), 114-122. https://doi.org/10.1093/poq/nfz003

Dryzek, J. S., Norgaard, R. B., \& Schlosberg, D. (2011). Climate change and society: approaches and responses. In J. S. Dryzek, R. B. Norgaard, \& D. Schlosberg (Eds.) The Oxford handbook of climate change and society (pp. 3-17). New York: Oxford University Press. https://doi.org/10.1093/oxfordhb/9780199566600.003.0001.

Dunlap, R. \& McCright, A. (2011). Organized climate change denial. In J. S. Dryzek, R. B. Norgaard, \& D. Schlosberg (Eds.) The Oxford handbook of climate change and society (pp. 144-174). New York: Oxford University Press. https://doi.org/10.1093/oxfordhb/9780199566600.003.0010. 
Eckstein, K., Noack, P., \& Gniewosz, B. (2013). Predictors of intentions to participate in politics and actual political behaviors in young adulthood. International Journal of Behavioral Development, 37(5), 428-435.

Election Project. (n.d.) "Voter Turnout Data," United States Elections Project, www.electproject.org/home/voter-turnout/voter-turnout-data.

Fabina, J. (2021, April 29). Despite Pandemic Challenges, 2020 Election Had Largest Increase in Voting Between Presidential Elections on Record. US Census Bureau. https://www.census.gov/library/stories/2021/04/record-high-turnout-in2020-general-election.html\#: :text=For\%20citizens\%20ages\% 2018\%2D34,compared\%20to\%2071\%25\%20in\%202016.

Feldman, L., \& Hart, P. S. (2016). Using political efficacy messages to increase climate activism: The mediating role of emotions. Science Communication, 38(1), 99-127.

Feldman, L., Hart, P. S., \& Milosevic, T. (2017). Polarizing news? Representations of threat and efficacy in leading US newspapers' coverage of climate change. Public Understanding of Science, 26(4), 481-497.

Feng, S., Oppenheimer, M., \& Schlenker, W. (2012). Climate change, crop yields, and internal migration in the United States (No. w17734). National Bureau of Economic Research. https://doi.org/10.3386/w17734.

Gerrard, M. B. (2016). United States Climate Change Law. In K. R. Gray, R. Tarasofsky, \& C. Carlarne (Eds.) The Oxford handbook of international climate law (pp. 317). New York: Oxford University Press. 10.1093/law/9780199684601.003.0027

Garrett, R. K., Long, J. A., \& Jeong, M. S. (2019). From partisan media to misperception: Affective polarization as Mediator. Journal of Communication, 
$69(5), 490-512$.

Glasford, D. E. (2008). Predicting voting behavior of young adults: The importance of information, motivation, and behavioral skills. Journal of applied social psychology, 38(11), 2648-2672.

Halpern, D., Valenzuela, S., \& Katz, J. E. (2017). We face, I tweet: How different social media influence political participation through collective and internal efficacy. Journal of Computer-Mediated Communication, 22(6), 320-336.

Hart, P. S., \& Feldman, L. (2016). The influence of climate change efficacy messages and efficacy beliefs on intended political participation. (8), e0157658.

Hoffman, L. H. (2015). Political Knowledge. In Oxford Research Encyclopedia of Communication.

Hong, H. (2011) An extension of the extended parallel process model (eppm) in television health news: The influence of health consciousness on individual message processing and acceptance, Health communication, 26(4), 343-353, DOI: $10.1080 / 10410236.2010 .551580$

Iyengar, S., Lelkes, Y., Levendusky, M., Malhotra, N., \& Westwood, S. J. (2019). The origins and consequences of affective polarization in the United States. Annual Review of Political Science, 22, 129-146.

Jackson, R. A. (1995). Clarifying the relationship between education and turnout. American Politics Quarterly, 23(3), 279-299.

Jamieson, D. (2011). The nature of the problem. In J. S. Dryzek, R. B. Norgaard, \& D. Schlosberg (Eds.) The Oxford handbook of climate change and society (pp. 3854). New York: Oxford University Press. 
https://doi.org/10.1093/oxfordhb/9780199566600.003.0003.

Leighley, J. E., \& Nagler, J. (2013). Who votes now?: Demographics, issues, inequality, and turnout in the United States. Princeton University Press.

Levendusky, M. (2013). Partisan media exposure and attitudes toward the opposition. Political communication, 30(4), 565-581.

Levendusky, M. S. (2018). Americans, not partisans: Can priming American national identity reduce affective polarization? The Journal of Politics, 80(1), 59-70.

Leventhal, H. (1970). Findings and theory in the study of fear communications. In Advances in experimental social psychology (Vol. 5, pp. 119-186). Academic Press. https://doi.org/10.1016/s0065-2601(08)60091-x.

Lewis, I., Watson, B., \& White, K. M. (2013). Extending the explanatory utility of the EPPM beyond fear-based persuasion. Health Communication, 28(1), 84-98.

Li, S. C. S. (2014). Fear appeals and college students' attitudes and behavioral intentions toward global warming. The Journal of Environmental Education, 45(4), 243257.

Lundgreen, R. E., \& McKaien, A. H. (2013). Risk communication: A handbook for communicating environmental safety, and health risks. New York: Wiley.

Lyon, T. \& Maxwell, J. (2008). Corporate social responsibility and the environment: A theoretical perspective. Review of Environmental Economics and Policy, 2(2), 240-260.

Koski, C. (2010). Greening America's skylines: The diffusion of low-salience policies. Policy studies journal, 38(1), 93-117. https://doi.org/10.1111/j.15410072.2009.00346.x. 
Marx, P., \& Nguyen, C. (2016). Are the unemployed less politically involved? A comparative study of internal political efficacy. European Sociological Review, 32(5), 634-648.

Matsusaka, J. G., \& Palda, F. (1999). Voter turnout: How much can we explain?. Public choice, 98(3-4), 431-446.

May, P. J. (1991). Addressing public risks: Federal earthquake policy design. Journal of Policy Analysis and Management, 10(2), 263-285. https://doi.org/10.2307/3325175.

McCright, A. M., \& Dunlap, R. E. (2003). Defeating Kyoto: The conservative movement's impact on US climate change policy. Social problems, 50(3), 348373. https://doi.org/10.1525/sp.2003.50.3.348.

Mendelsohn, R., Dinar, A., \& Williams, L. (2006). The distributional impact of climate change on rich and poor countries. Environment and development economics, 159-178. https://doi.org/10.4324/9781315257570-21.

Morrell, M. E. (2003). Survey and experimental evidence for a reliable and valid measure of internal political efficacy. The Public Opinion Quarterly, 67(4), 589-602.

Moser, S., \& Dilling. (2011). Communicating climate change: Closing the science-action gap. In J. S. Dryzek, R. B. Norgaard, \& D. Schlosberg (Eds.) The Oxford handbook of climate change and society (pp. 161-174). New York: Oxford University Press. https://doi.org/10.1093/oxfordhb/9780199566600.003.0011. Myers, T. A., Nisbet, M. C., Maibach, E. W., \& Leiserowitz, A. A. (2012). A public health frame arouses hopeful emotions about climate change. Climatic change, 113(3-4), 1105-1112. 
Niemi, R. G., Craig, S. C., \& Mattei, F. (1991). Measuring internal political efficacy in the 1988 National Election Study. The American Political Science Review, 14071413.

Norris, M. (2015). The economic roots of external efficacy: Assessing the relationship between external political efficacy and income inequality. Canadian Journal of Political Science, 48(4), 791.

O'Connor, R. E., Bard, R. J., \& Fisher, A. (1999). Risk perceptions, general environmental beliefs, and willingness to address climate change. Risk analysis, 19(3), 461-471.

Omotayo, F., \& Folorunso, M. B. (2020). Use of Social Media for Political Participation by Youths. JeDEM-eJournal of eDemocracy and Open Government, 12(1), 133158.

Parker, K., Morin, R., \& Horowitz, J. M. (2019, March 21). Looking to the future, public sees an America in decline on many fronts [Report]. https://www.pewsocialtrends.org/2019/03/21/retirement-social-security-and-longterm-care/

Persily, N. \& Stewart III, C. (2021). The Miracle and Tragedy of the 2020 US Election. Journal of Democracy, 32(2).

Pew Research Center (2019, February 5). Republicans and Democrats differ over key priorities for the president and Congress in 2019 [Table]. In B. Jones (Author) Republicans and Democrats have grown further apart on what the nation's top priorities should be. https://www.pewresearch.org/fact-tank/2019/02/05/republicans-and-democrats- 
have-grown-further-apart-on-what-the-nations-top-priorities-should-be/

Popova, L. (2012). The extended parallel process model: Illuminating the gaps in research. Health Education \& Behavior, 39(4), 455-473.

Prior, M. (2010). You've either got it or you don't? The stability of political interest over the life cycle. The Journal of Politics, 72(3), 747-766.

Prior, M. (2018). Hooked: How politics captures people's interest. Cambridge University Press.

Quintelier, E., \& Blais, A. (2016). Intended and reported political participation. International Journal of Public Opinion Research, 28(1), 117-128.

Recognizing the duty of the Federal Government to create a Green New Deal, H.R. 109, 116th Cong. (2019). https://www.congress.gov/116/bills/hres109/BILLS-

\section{6hres109ih.pdf}

Reichert, F. (2016). How internal political efficacy translates political knowledge into political participation: Evidence from Germany. Europe's Journal of Psychology, 12(2), 221.

Ruhrmann, G. (2008). Risk communication. The international encyclopedia of communication.

Riker, W. H., \& Ordeshook, P. C. (1968). A Theory of the Calculus of Voting. The American Political Science Review, 62(1), 25-42.

Rogers, R. W. (1975). A protection motivation theory of fear appeals and attitude change. The journal of psychology, 91(1), 93-114. https://doi.org/10.1080/00223980.1975.9915803.

Rumbul, R. (2016). ICT and citizen efficacy: The role of civic technology in facilitating 
government accountability and citizen confidence. In IFIP World Information Technology Forum (pp. 213-222). Springer, Cham.

Ryfe, D. M. (2001). History and political communication: An introduction. Political Communication, 18(4), 407-420.

Scheller, S. (2019). The strategic use of fear appeals in political communication. Political Communication, 36(4), 586-608.

Sherman, S. R. (1989). Public attitudes toward social security. Soc. Sec. Bull., 52, 2.

Shore, J. (2020). How social policy impacts inequalities in political efficacy. Sociology Compass, 14(5), e12784.

Smith, P., \& Gregory, P. J. (2013). Climate change and sustainable food production. Proceedings of the Nutrition Society, 72(1), 21-28.

Social Security Administration (2019, April 22). The 2019 Annual Report of the Board of Trustees of the Federal Old-age and Survivors Insurance and Federal Disability Insurance Trust Funds [Report]. https://www.ssa.gov/oact/TR/2019/tr2019.pdf

Stapleton, C. E. (2020). Why so Angry? Understanding the Influences of Elite Anger on the American Electorate (Doctoral dissertation, University of Colorado at Boulder).

Thaker, J. (2012). Climate change in the Indian mind: Role of collective efficacy in climate change adaptation. George Mason University.

U.S. House of Representatives, Office of the Clerk. (2012). Table no. 397. Participation in Elections for President and U.S. Representatives: 1932 to 2010. Statistical abstract of the United States: 2012 (p. 244). Washington, D.C.: U.S. Census Bureau. 
Velasquez, A., \& LaRose, R. (2015). Youth collective activism through social media: The role of collective efficacy. New Media \& Society, 17(6), 899-918.

Witte, K. (1992). Putting the fear back into fear appeals: The extended parallel process model. Communications Monographs, 59(4), 329-349. https://doi.org/10.1080/03637759209376276.

Witte, K. (1994). Fear control and danger control: A test of the extended parallel process model (EPPM). Communications Monographs, 61(2), 113-134. https://doi.org/10.1080/03637759409376328.

Witte, K., \& Allen, M. (2000). A meta-analysis of fear appeals: Implications for effective public health campaigns. Health Education \& Behavior, 27(5), 591-615. https://doi.org/10.1177/109019810002700506.

Witte, K., Cameron, K. A., McKeon, J. K., \& Berkowitz, J. M. (1996). Predicting risk behaviors: Development and validation of a diagnostic scale. Journal of Health Communication, 1(4), 317-341. https://doi.org/10.1080/108107396127988.

Wolfinger, R. E., \& Rosenstone, S. J. (1980). Who votes?. Yale University Press.

Yang, P., \& Barrett, N. (2006). Understanding public attitudes towards Social Security. International Journal of Social Welfare, 15(2), 95-109. https://doi.org/10.1111/j.1468-2397.2006.00382.x. 


\section{Appendix: Demographic Regression}

Table 8.

Results of Multiple Regression Analysis With Demographic Variables as the Determinants

\begin{tabular}{lccccccc}
\hline & $\beta$ & $t$ & $p$ & $F$ & $d f$ & $p$ & $R^{2}$ \\
\hline Overall model & & & & .384 & 5,169 & .859 & -0.18 \\
Age & -.96 & -1.03 & .303 & & & & \\
Education Level & .10 & 1.13 & .258 & & & & \\
Ethnicity & .03 & 0.34 & .736 & & & & \\
Income & -.03 & -0.38 & .702 & & & & \\
Sex & -.02 & -0.31 & .755 & & & & \\
\hline
\end{tabular}

